\title{
Superheated steam application to optimize the kiln drying of rubberwood (Hevea brasiliensis)
}

\begin{abstract}
A study was conducted to optimize the kiln drying of $50 \mathrm{~mm}$ thick rubber wood boards using a combination of superheated steam and hot air. The results revealed that initial application of saturated steam at $100{ }^{\circ} \mathrm{C}$, followed by a period of superheated steam application at $110{ }^{\circ} \mathrm{C}$ and finally drying in hot air at $65^{\circ} \mathrm{C}$ as in the conventional kiln drying, gave the best result in terms of minimizing drying defects and also shortening the drying time.
\end{abstract}

Keyword: Steam; Superheated steam; Moisture gradient; Saturated steam; South East Asian region 